\title{
TAREKAT SUFIYAH ISLAM DALAM PEMIKIRAN TASAWUF H. ABDUL MUIN HIDAYATULLAH
}

\author{
Murjani Sani*
}

\begin{abstract}
This paper describes only the existence of Islamic Sufiyah tarekat (TSI) in the thought of $H$. Abdul Muin Hidayatullah. The results show that the TSI was built by H. Abdul Muin since 1955 after he was brought into a spiritual meeting with Rasulullah, Prophet Adam and Moses as well as 40 leaders of an Islamic state. At that time, he had been inducted as a murshid Zabir tarekat, while Murshid is the Messenger of Allah. That's when it started developing tarekat until he passed away, 1995 at the age of 87 years. Murshid was replaced by his own son, K.H. Abdullah al-Mahdi and develop it until now. The Islamic Sufiyah Tarekat is growing quite rapidly; reaching 7,000 people are now members, consisting of listeners, students, followers and supporters. They spread in South Kalimantan, especially in Banjarmasin, and in the District Tabunganen Tabalong, and actively carry out the teaching daily deed specified. It is in meaningful, positive impact on the development of faith and piety of its members.
\end{abstract}

Kata kunci: silsilah, mursyid, wirid, zikir.

\section{Pendahuluan}

Salah satu disiplin ilmu keislaman adalah akhlak/tasawuf, tercermin dari dialog Nabi dengan Jibril tentang iman, Islam, ihsan. ${ }^{1}$ Ketiganya satu-kesatuan bagi kesempurnaan keislaman. Islam sebagai sistem ajaran yang lengkap, memberi tempat penghayatan keagamaan secara eksoterik (lahir) dan esoterik (batin).Tekanan berlebihan dari aspek itu menghasilkan kepincangan yang menyalahi ekuilibrium (tawazun $)^{2}$, Islam mengajarkan ekuilibrium itu (QS.28:27). Kenyataannya, masih banyak penghayatan keislaman lebih kepada yang lahiriah dan atau kepada yang batiniah

Nabi mendeskripsikan ihsan sebagai dimensi terdalam setelah iman dan Islam. Ihsan, yaitu bahwa engkau menyembah Allah seakan melihat-Nya, jika

\footnotetext{
*Dosen tetap Fakultas Ushuluddin IAIN Antasari Banjarmasin.

${ }^{1}$ Imam Muslim, Shabih Muslim, Juz I, (Bandung: PT. al-Ma'arif, t.th), h. 23-24.

${ }^{2}$ Amin Syukur, Menggugat Tasawnf, (Yogyakarta: Pustaka Pelajar, 2002), cet. I, h. 133.
} 
tidak, Dia melihat engkau. ${ }^{3}$ Ihsan terkait ketasawufan karena menyangkut kedekatan dengan Allah, melatih jiwa bebas dari pengaruh dunia, tercermin akhlak mulia, berada sedekat-mungkin dengan Allah. ${ }^{4}$ Tasawuf terkait pembinaan rohani bagi kedekatan dengan Allah melalui ketekunan beribadah dan menjauhi kemewahan duniawi, ${ }^{5}$ menuju makrifat dan tersingkapnya dinding dengan-Nya. ${ }^{6}$

Ada beragam pendapat tentang asal kata tasawuf; dari lafal shuf (bulu domba), shafa (bersih), shaf (barisan terdepan), shuffah (emperan Mesjid Nabawi). Menurut Asywadie Syukur cenderung dari kata shuf, karena pakaian demikian menunjukkan kesederhanaan, pencegah riya, lambang sufi. Ajarannya dinamai tasawuf. ${ }^{7}$ Secara terminologi; diartikan ke luar dari sifat tercela menuju sifat terpuji melalui latihan (rijadhah) dan kesungguhan (mujahadab). Berintikan kesadaran adanya komunikasi dengan Tuhan, manifestasi ihsan, wujud kualitas penghayatan agama, bagi membangun dorongan terdalam dan realisasi diri secara utuh sebagai makhluk. Secara hakiki, tasawuf bersifat kerohanian dan potensi besar bagi mengenal diri sebagai sarana mengenal Tuhan. ${ }^{8}$ Tujuannya berada sedekat-mungkin dengan Allah melalui tarekat, karena tarekat adalah jalan yang harus ditempuh untuk berada dekat Allah, ${ }^{9}$ dengan istigfar, zikir dan lain-lain. Tarekat, cara mendekatkan diri kepada Allah dengan mengamalkan tauhid, fikih dan tasawuf. ${ }^{10}$

Di permulaan Islam ada tarekat Nabawiyah berupa amalan yang dilaksanakan secara murni pada masa Rasul. Ada Salafiyah, amalan yang dilakukan masa sahabat. Setelah abad II H, terjadi perkembangan bertujuan menyucikan diri melalui syariat, tarekat, hakikat, dan makrifat. Syariat, mengamalkan ketentuan syariat secara lahiriyah. Tarekat, mengerjakan amalan hati (batin) dengan akidah yang kokoh. Hakikat, cahaya musyahadah yang

${ }^{3}$ Imam Muslim, Shabih Muslim ..., h. 23-24

${ }^{4}$ Harun Nasution, Filsafat dan Misticisme dalam Islam (Jakarta: Bulan Bintang, 1990), cet. VII, h. 56. Abuddin Nata, Akblak Tasawuf, (Jakarta: PT. RajaGrafindo Persada, 2002), cet. IV, h. $180-182$.

${ }^{5}$ Mustafa Zahri, Kunci Memahami Ilmu Tasawnf, (Surabaya: PT. Bulan Bintang, 1979), h. $138-139$.

${ }^{6}$ Muhammad Saifullah al-Aziz; Risalah Memahami Ilmu Tasawnf, (Surabaya: PT. Terbit Terang, 1998), h. 40.

${ }^{7}$ M. Asywadie Syukur, Imu Tasamuf, Jilid I, (Surabaya: PT. Bina Ilmu, 1978), h. 7.

${ }^{8}$ M. Amin Syukur, Menggugat Tasawnf..., h. 1-2.

${ }^{9}$ Harun Nasution, Filsafat..., h. 89.

${ }^{10}$ Ahmadi Isa, Ilmu Tarikat, (Banjarmasin: Pascasarjana IAIN Antasari, 2005), h. 8. 
bersinar di hati, hingga mengetahui hakikat Allah dan rahasia alam. Makrifat, mencapai kesucian di alam rohani, memiliki pandangan tembus (kasyf) dan mengetahui hakikat kebesaran Ilahi. Orang sufi menganggap syariat memperbaiki yang nyata, tarekat memperbaiki yang tersembunyi, hakikat memperbaiki rahasia gaib, dan makrifat mengenal hakikat zat Allah, sifat dan perbuatan-Nya. Tarekat menonjol abad XII M ditandai silsilah dan pendirinya, karenanya setiap tarekat ada mursyid, cara zikir dan upacara ritual, ${ }^{11}$ mulanya bersifat individual kemudian menjadi organisasi. Awal munculnya di Asia Tengah, Tibristan, Bagdad, Irak, Turki, Arab, Indonesia, Malaysia, Singapura, Thailan dan Tiongkok, ${ }^{12}$ tersebut nama tarekat Rifa'iyah, Syukbrawardiyah. Di Indonesia muncul tarekat Qadiriyah, Syaziliyah, Naqsyabandiyah, Khalwatiyah, Syattariyah, Sammaniyah, Tijaniyah, Qadiriyah wa Naqsyabandiyah, ${ }^{13}$ Rifa'iyah alHaddad, Khalidiyah, ${ }^{14}$ al-Tijaniyah. ${ }^{15}$ Di abad ke XII H ini tercatat ada 41 buah tarekat muktabarah yang memenuhi kemuktabarahannya, seperti adanya mursyid, cara zikir dan upacara ritual. Sementara di dunia Islam ditemukan ada 102 buah tarekat yang namanya dinisbahkan kepada pendirinya. ${ }^{16}$

Di Kalimantan Selatan ditemukan tarekat al-Tijaniyah, Sammaniyah, Qadiriyah wa al-Naqsyabandiyah, ${ }^{17}$ Junaidiyah, Alawiyah, Syaziliyah, ${ }^{18}$ belum termasuk yang tidak terdeteksi, seperti Tarekat Sufiyah Islam (TSI) ini. TSI dipimpin H. Abdul Muin Hidayatullah (H. Abdul Muin), setelah ia meninggal dunia tahun 1995, kepemimpinan tarekat ini dilanjutkan oleh mursyid berikutnya yaitu anaknya sendiri, K.H. Abdullah al-Mahdi sampai sekarang. Dengan sistem kekeluargaan tarekatnya sebagaimana tarekat lainnya, meliputi mursyid, silsilah, pengikut, suluk, wirid dan praktiknya.

H. Abdul Muin selaku mursyid pertamanya, berlatarbelakang pendidikan sebagai alumni Pendidikan Guru Agama Negeri (PGAN) 6 Tahun dan sempat 'mengaji duduk' dengan beberapa orang tokoh agama. Ilmu tarekat menurutnya diperoleh melalui khalwat hingga memperoleh kasyf. Ia mengaku pernah

${ }^{11}$ Ahmadi Isa, Ilmu Tarikat ..., h. 9.

${ }^{12}$ A hmadi Isa, Ilmu Tarikat ..., h. 11.

${ }^{13}$ Sri Mulyati, et. al Mengenal dan Memahami Tarikat-Tarikat Muktabarab di Indonesia, (Jakarta: PT. Pranada Media, 2004), h. ix.

${ }^{14}$ Abuddin Nata, Akblak Tasawnf..., h. 273.

${ }^{15}$ Syafruddin, Tarikat Tijaniyah di Kalimantan Selatan (Studi Sejarah dan Motivasi Masyarakat Masuk Tarikat, (Tesis), (Banjarmasin: Pascasarjana IAIN Antasari, 2003), h. 4.

${ }^{16}$ Ahmadi Isa, Ilmu Tarikat, h. 13-17,

${ }^{17}$ Sri Mulyati, et.al, Mengenal..., h. 102, 184, 194, 288.

${ }^{18}$ Syafruddin, Tarikat..., h. 4 
dibawa ke alam gaib dan bertemu dengan Rasulullah, nabi Adam, nabi Musa dan 40 orang pimpinan negara Islam. Sementara mursyid penggantinya yaitu K.H.Abdullah al-Mahdi hanya berpendidikan tingkat sekolah dasar. Dia mendapat wasiat dari orang-tuanya untuk melanjutkan kepemimpinan tarekat ini. Orang-tuanya berkata; 'terimalah amanah ini, nanti akan diberi ilmu dari dalam', maksudnya akan dituangkan pengetahuan rohani secara batin.

Silsilah berupa nisbah hubungan mursyid terakhir sambung-menyambung hingga Rasulullah, merupakan legitimasi muktabarah-tidaknya sebuah tarekat, ${ }^{19}$ sementara silsilah mursyid bagi TSI ini tidak bersambung, karena mursyidnya mengaku bertemu langsung dengan Rasulullah dan mendapatkan ajaran dari beliau.

Keberadaan TSI ini tidak banyak diketahui orang, terutama di kalangan akademisi. Sementara di kalangan 'awam' berkembang 'issu' bahwa TSI ini bersifat eksklusif (tertutup), kecuali antar pengikut yang bisa berinteraksi. Hal ini menarik untuk dikaji secara ilmiah melalui penelitian, dan ternyata 'issu' eksklusif tersebut tidak terbukti. Sebab pada prinsipnya, TSI ini membuka diri bagi siapa saja yang berkeinginan untuk menjadi anggotanya. Karena itu pada tahapan awal fokus kajian dan permasalahan tulisan ini dibatasi pada 'mendeskripsikan keberadaannya' saja, yang meliputi; asal-usul, perkembangan, mursyid dan silsilah, pengikut, suluk, wirid dan praktiknya dalam kehidupan. Menyangkut bagaimana dampaknya bagi para anggota termasuk pro-kontra terhadap silsilah mursyidnya yang tidak bersambung itu, memerlukan analisis dan penelitian tersendiri.

\section{Tarekat Sufiyah Islam (TSI)}

\section{Asal-Usul dan Perkembangan}

Tarekat adalah jalan yang harus dilalui untuk meraih kesucian lahir-batin, begitu juga TSI yang didirikan di Banjarmasin tahun 1377/1955 oleh H. Abdul Muin. Malam ke 17 Ramadhan ia khalwat di rumahnya, Jalan Meratus Banjarmasin Tengah. Mengamaliahkan wirid tarekat Syaziliyah yang dipelajari sebelumnya. Dijemput dan dibawa ke alam gaib di Gunung Keramaian Tanah Laut Kalimantan Selatan. Bertemu tokoh-tokoh rohani: Nabi Muhammad, Adam, Musa, dan 40 tokoh negara Islam. Acaranya, peleburan tarekat pimpinan Nabi menjadi TSI. Mursyid rohaninya Nabi Muhammad dan H. Abdul Muin mursyid zahirnya. Sejak itu berdirilah tarekat ini dengan amaliah

${ }^{19}$ Sri Mulyati, et.al, Mengenal..., h. 9-10. 
yang diperoleh melalui khalwat. Mulanya diikuti beberapa orang, kemudian makin banyak hingga membuka cabang di Anjir, Tabunganen dan Tanjung. Berpusat di Bait al-Mukarramah, sebuah pondok yang dibangun di atas tanah 40 x $40 \mathrm{~m}$. Di lantai atas ada aula wadah amaliah, shalat dan lain-lain. Di lantai bawah ada ruang rapat, 20 kamar untuk kegiatan suluk. Kantor Yayasan, TK alQur'an, tempat wudhu dan kubah H. Abdul Muin bersama isteri. Pondok ini khusus untuk kegiatan TSI berupa suluk pembinaan anggota.

\section{Tujuan}

Tujuan TSI kesucian lahir-batin sarana makrifatullab dengan amaliah utama zikir bi al qalb dan istigfar permohonan ampun disertai amaliah menuju makrifat sebab mula-mula agama mengenal Allah. ${ }^{20}$ Makrifat diawali mengenal diri, maksudnya bahwa sifat kudrat, iradat, ilmu, hayat, sama', bashar, kalam, ada pada kita, harus diyakini bukan milik kita. Bila 'taakui' milik kita hukumnya syirik dan penghalang makrifat, disebabkan karena nafsu, seseorang harus berupaya menguasai nafsu yang mendindingnya dengan Allah. Kalau sudah makrifat, berbuat, melihat dan mendengar, hakikatnya adalah Allah, dan makrifat yang dikehendaki disertai amaliah yang ditentukan. ${ }^{21}$

Tujuan di atas senada dengan teori sufistik berupa takhalli (membersihkan diri dari sifat tercela), taballi (mengisinya dengan sifat terpuji) dan tajalli (memperoleh kenyataan Tuhan). ${ }^{22}$ Makrifat berarti pengetahuan/ pengalaman, ${ }^{23}$ pengetahuan tentang rahasia hakikat agama, objeknya lebih kepada batin. Hal ini didasarkan bahwa akal mampu mengetahui hakikat ketuhanan, hakikat itu satu, yang maijud berasal dari yang satu, ${ }^{24}$ atau pengetahuan tentang Tuhan melalui hati. Pengetahuan itu demikian jelas hingga jiwanya merasa satu dengan yang diketahui (Tuhan). ${ }^{25}$ Ketetapan hati dalam mempercayai hadirnya yang wajib al-wujud (Allah) ${ }^{26}$ Tegasnya, makrifat adalah mengetahui Tuhan dari dekat hingga hati dapat melihat-Nya.

${ }^{20}$ Wawancara dengan H. Abdullah al-Mahdi, ..., Banjarmasin, 20 Maret 2006.

${ }^{21}$ Wawancara dengan H. Abdullah al-Mahdi, ..., Banjarmasin, 24 Maret 2006.

${ }^{22}$ Mustafa Zahri, Kunci Memahami Ilmu Tasawnf, (Surabaya: PT. Bina Ilmu, 1998), h. 65

${ }^{23}$ Proyek Pembinaan Perguruan Tinggi Agama IAIN Sumatera Utara, Pengantar Ilmu Tasawnf, (Sumatera Utara: 1981/1982), h. 122.

24Jamil Saliba, Mu'jam al-Falsafi, Jilid II, (Beitut: Dar al- Kitab, 1979), h, 72.

${ }^{25} \mathrm{Al}-\mathrm{Kalabazi}$, al-Ta'arruf li al-Mazhab Abl al-Tasawmuf, (Mesir: Dar al-Qahirah, t.th), h. $158-159$.

${ }^{26}$ A. Mustofa, Akblak Tasawnf, (Bandung: CV. Pustaka Setia, 1999), Cet. II (Revesi) h. 251 
Tokoh teori ini al-Gazali dan Zu al-Nun al-Misri, keduanya mengatakan bahwa makrifat adalah pengetahuan tentang rahasia Tuhan yang diberikan melalui pancaran cahaya-Nya. Dimasukkan-Nya ke hati hingga bisa berhubungan dengan nur Tuhan, dan hal ini mungkin saja terjadi. Dalam alQur'an ada 43 kali lafal nur disebutkan, seperti QS. 24:40 dan QS. 39:22. ${ }^{27}$ Ayat ini memperjelas bahwa cahaya Tuhan bisa diberikan kepada yang dikehendakiNya. 'Aku (Allah) adalah perbendaharaan tersembunyi. Aku ingin memperkenal kan siapa Aku, maka Aku ciptakan makhluk. Aku memperkenalkan diri kepada mereka, mereka pun mengenal Aku. Hadis ini menunjukkan bahwa Allah dapat dimakrifati dengan meneliti ciptaan-Nya, bisa terjadi dan tidak bertentangan dengan Islam. ${ }^{28}$

Makrifat dalam TSI melalui riyadhah, mujahadah, musyahadah, muraqabah, tawajjuh, mababbah dan mukasyafah. Dalam sufistik melalui qalb, roh, dan sir, qalb untuk merasa dan berpikir, dapat mengetahui hakikat yang ada. Jika qalbu dilimpahi cahaya Tuhan, maka ia bisa mengetahui rahasia-Nya. Qalb yang bersih dari dosa dapat mengetahui rahasia Tuhan, erat hubungannya dengan takhalli, taballi dan tajalli. ${ }^{29}$ Jadi ajaran TSI ada kesamaan dengan yang berkembang di dunia sufi.

\section{Mursyid}

Dalam sufistik ditemukan beberapa sebutan bagi pimpinan tarekat: mursyid, syekh, dan guru. Dalam TSI disebut 'mursyid' (penunjuk jalan kebenaran). Mursyid pertama H. Abdul Muin, penggantinya H. Abdullah alMahdi. Sebagai penunjuk jalan kebenaran, mengisyaratkan tugasnya yang tidak ringan, membina anggota menuju makrifat, bila terlaksana dengan baik beruntunglah, bila tidak apalagi yang disampaikan kontradiksi dengan syariat dan tidak diamalkan, dibenci Allah (QS. 61: 2-3).

Syarat mursyidnya cukup berat: belajar dengan ahlinya, memahami ilmu hakikat, mengamalkan, bermimpi bertemu Rasul dan diamanahi menyampaikan ajaran. ${ }^{30}$ Penyebutan guru dengan mursyid sama dengan teori sufistik, meski ada sebutan lain seperti syekh atau badal syekh. Kriteria mursyid dalam teori sufistik; alim, arif, jujur, bijaksana, tawadhu', sabar, professional

${ }^{27}$ Abuddin Nata, Akblak Tasawnf..., h. 225-230.

${ }^{28}$ Abuddin Nata, Akblak Tasawnf..., h. 230.

${ }^{29}$ Abuddin Nata, Akblak Tasawnf..., h. 222

${ }^{30}$ Wawancara dengan $H$. Saberi/H. Abdulllah al-Mahdi, Wakil/Mursyid TSI, Banjarmasin, 14 Mei 2006. 
dan mampu menyimpan rahasia, ${ }^{31}$ sementara al-Kurdi mengemukakan 24 kriterianya, yang di antaranya ada kesamaan dengan TSI.

\section{Silsilah}

Silsilah adalah hubungan sambung-menyambung mursyid terakhir dengan pendahulunya sampai kepada Rasulullah. Hal ini sangat penting bagi sebuah tarekat, tolok-ukur muktabarah-tidaknya, agar bimbingan mursyid benar dari Rasul. Apabila bukan emikian berarti putus/palsu, dan bukan dari Nabi. Meski sebagian sufi menerima ajaran guru dari hasil komunikasi langsung/spiritual (liqa barzakbi). ${ }^{32}$ Namun bagi TSI, silsilahnya tidak bersambung, mursyidnya mengaku bertemu Rasul melalui khalwat malam 17 Ramadhan 1377. Ia dijemput dipertemukan di alam gaib dengan Nabi Muhammad, Adam, Musa, dan lain-lain. Dibentuklah TSI, Nabi Muhammad mursyid rohaninya dan $\mathrm{H}$. Abdul Muin mursyid zahirnya. Peristiwa ini dibuktikan masyarakat, sehingga mereka menanyakan apa yang terjadi. penulis katakan ada peleburan tarekat dan saya dibai'at mursyid zahirnya. ${ }^{33}$ Dengan demikian, dapat disimpulkan bahwa TSI ini silsilahnya tidak bersambung.

Ketidak-bersambungan silsilah tersebut sama dengan yang terjadi pada Tarekat al-Tijaniyah. Pendirinya (Muhammad al-Tijani $(1150 \mathrm{H})^{34}$. Menurut Laily Mansur, ketika al-Tijani khalwat bermimpi bertemu Rasulullah dan mengajarinya istigfar, shalawat, kemudian menyuruhnya mendirikan tarekat dan meninggalkan tarekat lainnya. ${ }^{35}$ Empat tahun kemudian Rasulullah kembali menemuinya dan mengajarinya hailalah (Lailahaillallab) ${ }^{36}$.

Terhadap silsilah yang tidak bersambung ini ada dua pendapat; mempermasalahkannya sebab salah-satu kriteria tarekat adalah silsilahnya bersambung. Toleran atau tidak mempermasalahkannya dengan alasan bahwa alam ini ada yang bersifat fisik dan ada pula yang non fisik. Yang fisik bisa bertemu antar sesamanya, dan yang non fisik bisa saja bertemu melalui mimpi. Menurut Ahmadi Isa, Guru Besar Tarekat Pascasarjana IAIN Antasari, bahwa

${ }^{31} \mathrm{Abu}$ Bakar Atjeh, Pengantar Ilmu Tarikat, Kajian Historis tentang Misitik, (Solo: Ramadhani, 1994), h. 80-84

${ }^{32}$ Sri Mulyati et.al, Mengenal..., h. 9-10

${ }^{33}$ Wawancara dengan H. Abdullah al-Mahdi, ..., Banjarmasin, 24 Maret 2006.

${ }^{34}$ HAR Gibb, et al, Shorter Ensycklopedia of Islam, (Leiden; New York, EJ. Bril, 1991), h. 592-594.

${ }^{35}$ M. Laily Mansur, Ajaran dan Teladan Para Sufi (Jakarta; Bulan Bintang, 1990), h. 285. Lihat jug Muhamma bin Abdullah bin al-Husain, al-Fath al-Rabbanny fi ma Yabtaj Ilaih al-Murid al-Tijani, (t.tp, tth) h. 6-10.

${ }^{36}$ M. Laily Mansur, Ajaran ..., h. 280. 
pertemuan rohani dengan Rasulullah bisa saja terjadi, begitu jug antar tokoh tarekat. Abdul Qadir Jailani pernah memberi jubah kepada Syekh Samman padahal tidak pernah bertemu secara fisik. Memang menurut Martin Van Bruinessen, bagi tarekat yang silsilahnya tidak bersambung ada yang mengatakan palsu, sehingga menolaknya, namun ada juga yang menerima. Hal ini perlu dikaji apalagi petunjuk al-Qur'an maupun hadis yang mendukungnya belum ditemukan. ${ }^{37}$

\section{Murid/Anggota}

Murid/anggota TSI ada 7.000 orang, di Banjrmain 1.000 orang, di Anjir 1.000 orang, di Tabunganen 2.000 orang dan di Tanjung 3.000 orang. Di antara mereka adalah pedagang, petani dan wiraswasta. Syarat menjadi murid/anggota ini tidak mengikat, asal dewasa berusia 20 tahun ke atas, karena ilmu yang dipelajari adalah ilmu 'dalam' (tasawuf) dan kemauan sendiri tidak paksaan (QS.2: 256). Murid ada empat klasifikasi: (i) pendengar, anggota tingkat pemula, bergabung, melihat, mendengar, menyerap informasi bagi mempertimbangkan keikut-sertaannya. Status ini belum dicatat sebagai anggota, ia pendengar yang baik. (ii) pelajar, pendengar yang baik, bila menyatakan keikut-sertaan statusnya menjadi 'pelajar'. Mulai diadministrasikan terkait nama, tempat/tanggal lahir, pekerjaan, keluarga, alamat. (iii) pengikut, setelah 'pelajar' meningkat menjadi 'pengikut' mulai bertugas mengamalkan ajaran. (iv) pendukung, adalah anggota yang sebenarnya, mengamalkan ajaran, garis-depan, panutan, mantap keyakinan, menampung pertanyaan, pembantu kelangsungan TSI, dan penyebar ajaran kepada masyarakat. ${ }^{38}$

\section{Suluk/Khalwat}

Anggota berstatus pengikut harus mengikuti suluk dan pasca suluk. Suluk/khalwat adalah usaha menempuh jalan mencapai tujuan kesucian lahirbatin. ${ }^{39}$ Bentuknya latihan amaliah yang mirip dengan teori sufistik. Suluk dari salaka berarti menempuh perjalanan bagi mencapai tujuan, pelakunya disebut salik. ${ }^{40}$

${ }^{37}$ Asmaran, As, Aliran-Aliran Tarekat di Kalimantan Selatan ('Alawiyah, Sammaniyah dan Tijaniyah, dalam Jurnal Kebudayaaan Kandil Melintas Tradisi, Edisi 4 Tahun II, Februari 2004, h. 52 .

${ }^{38}$ Wawancara dengan H. Abdullah al-Mahdi, ..., Banjarmasin, 24 Maret 2006.

${ }^{39}$ Wawancara dengan H. Abdullah al-Mahdi, ..., Banjarmasin, 20 Maret 2006.

${ }^{40}$ M. Mustofa, Akblak Tasawnf, (Bandung: CV Pustaka Setia, 1999), cet. II (Revisi) h. 286. 
Pertama, Suluk pengikut, anggota yang baru memasuki status 'pengikut' wajib mengikuti suluk bimbingan mursyid, mengamalkan wirid di ruang tertentu yang ada tempat shalatnya. Dalam teori sufi disebut 'zawiyah', ruang pendidikan calon sufi yang ada mihrab shalat, zawiyah besar disebut asrama/madrasah. ${ }^{41}$ Syaratnya tidak boleh bicara dan makan makanan bernyawa, dan yang masak di atas api. Bagi yang SDM memadai dan menguasai ilmu rohani hanya beberapa hari, bagi yang kurang memadai dan tidak sibuk, bisa 10-40 hari. Setelah selesai ia berada pada status 'pengikut' dan mulai wajib mengamalkan wirid. Sayangnya suluk perubahan status ini tidak dilakukan lagi karena mursyidnya sering sakit dan belum ada izin. Pindah status dewasa ini hanya diberi arahan melestarikan amaliah. ${ }^{42}$

Suluk demikian sama dengan teori sufistik, yaitu usaha menempuh jalan mencapai tujuan, dengan melakukan riyadhah, mujahadah, pelakunya disebut salik. ${ }^{43}$ Ia jalan hidup dan latihan mental yang harus ditempuh anggota tasawuf/tarekat, ${ }^{44}$ tidak ada istilah pindah status atau tidak, sementara dalam TSI dilakukan menjelang pindah status. Suluk dalam tasawuf dimaknai mengosongkan diri dari sifat tercela mengisinya dengan sifat terpuji, dengan melestarikan amal lahir-batin dan melatih mujahadah, ${ }^{45}$ hal ini tidak disinggung TSI. Suluk sama dengan khalwat dalam TSI, mirip dengan teori tasawuf yang mengatakan bahwa khalwat satu rangkaian dengan suluk, menyendiri dan bertapa. $^{46}$

Kedua, Pasca suluk, setelah suluk peningkatan status selesai, maka status 'pengikut' menjadi 'pendukung'berarti berada pada pasca suluk. Pada pasca suluk anggota wajib melaksanakan amaliah TSI individual dan jama'i. Amaliah individualnya sama dengan yang dilakukan anggota diawal status pengikut, kecuali tambahan zikir dan asma al-husna. Amaliah jama'i hanya sekali/minggu/bulan dilakukan bersama anggota lain. Anggota berstatus pendukung adalah pengikut TSI yang sebenarnya, garis-depan, teladan, pembantu, dan bertugas menyebarkan TSI. ${ }^{47}$

\section{Kitab}

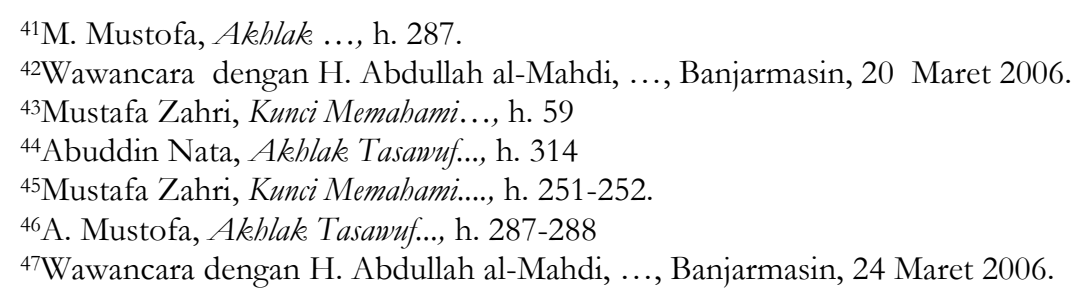


TSI ini tidak memiliki kitab pegangan khusus, materi ajaran mengarah Kitab al-Dur al-Nafis yang dulu pernah dipermasalahkan, sekarang tidak ada kritikan lagi, sebab 'tersirat' dan 'hakikat'. ${ }^{48}$ Kecuali itu ada Naskah stensilan Kumpulan Beberapa Naskah Hasil Perjalanan Tarekat Sufiyah Islam dihimpun H. Abdullah al-Mahdi. Al-Durr al-Nafis karya M. Nafis bin Idris al-Husain al-Banjari, yang lahir di Martapura dari keluarga Kerajaan Banjar. ${ }^{49}$ Tasawuf, salah-satu bidang yang ditekuninya. ${ }^{50}$ Kapan meninggal tidak diketahui, dimakamkan di Kalimantan Selatan ${ }^{51}$ meski dipertanyakan, karena tidak ada zuriatnya di daerah ini. ${ }^{52}$ Karyanya tersebut berisi uraian antara lain tentang Tuhan, tauhid afal, asma, sifat dan zat dan penciptaan manusia. Kendala gagalnya taqarrub adalah syirik khafi, riya, sum'ah, ujub dan hijab. Mencapai tujuan kesufian harus yakin segala sesuatu hakikatnya dari Allah. ${ }^{53}$

Naskab TSI mengarah al-Dur al-Nafis ada benarnya, seperti mendidik rajin ibadah, jangan tergoda dunia, menghindari akhlak tercela, makhluk tidak berdaya, segalanya milik Allah. Agar zikir, takwa, sabar, syukur, yakin, redha, ikhlas, tawakkal, mahabbah, jujur, iman dan tauhid, ${ }^{54}$ yang sarat nilai sufistik, namun tidak ada penjelasan termasuk masalah amaliah. Amaliah katanya hasil kasyf melalui khalwat, terbuka hijab dan diperoleh ilmu melalui hati. ${ }^{55}$

Kasyf demikian sama dengan teori sufistik, terbukanya hijab karena ibadah dan diperoleh hikmah di hati, ia menjadi bijaksana. Hikmah yang timbul dari hati karena tekun ibadah adalah kasyf. Ibnu Abbas mengatakan, 'muhaddats' dalam QS. 22: 52 adalah orang yang diberi ilham, mengetahui sesuatu dari hatinya, dapat ilmu tanpa belajar, kuncinya adalah takwa. Ulama adalah yang memperoleh ilmu dari Allah (ilmu rabbani) sesuai yang dikehendaki-Nya, ${ }^{56}$ atau

\footnotetext{
${ }^{48}$ Wawancara dengan H. Abdullah al-Mahdi, ..., Banjarmasin, 24 Maret 2006.

${ }^{49}$ M. Laily Mansur, Kitab al-Dur al-Nafis, Tinjanan Atas Suatu Ajaran Tasawuf (Banjarmasin, Hasanu, t.th) h. 12

${ }^{50}$ Ilham Masykuri Hamdi, Ajaran Tasawuf Syekh Mubammad Nafis al-Banjari (Skripsi) (Jakarta: IAIN Syarif Hidayatullah, 1989), h. 49-50.

${ }^{51}$ Ahmadi Isa, Ilmu Tarikat..., h. 31.

${ }^{52}$ M. Asywadie Syukur, Hasil Kuliah Pascasarjana, (Banjarmasin: IAIN Antasari 2006).

${ }^{53}$ Samdani, Syekh Mubammad Nafis al-Banjari dan Pemikiran Tasawnfnya (Makalah S2) (Banjarmasin: IAIN Antasari, 2005), h. 13.

${ }^{54} \mathrm{KH}$. Abdullah al-Mahdi dan H. Busra Noor bin H. Jumri, ..., h. 4.

${ }^{55}$ Wawancara dengan H. Abdullah al-Mahdi, ..., Banjarmasin, 24 Maret 2006.

${ }^{56}$ Abdul Halim Mahmud, Qadhiyah al- Tasawuf al- Munqiz min al- Dhalal, diterjemahkan oleh Abubakar Basymeleh dengan judul Hal-IhwalTasawnf, (Indonesia; Dar al- Ihya, tth), h. 8389.
} 
ilmu laduni (QS: 18: 65). Dalam TSI ilmu laduni sama dengan ilmu rabbani dalam sufistik. Ilmu laduni yang diperoleh mursyid lewat kasyf itu hendaknya dibukukan, dijadikan rujukan yang sangat diperlukan bagi sebuah tarekat seperti TSI.

\section{Amaliah dan Praktiknya}

TSI menekankan kesucian lahir-batin, nuansa sufistiknya tergolong maqam dan hal/abwal. Maqam adalah jalan panjang yang ditempuh sufi agar berada dekat Allah. ${ }^{57} \mathrm{Hal} /$ abwal, keadaan mental (senang, sedih, takut) datang sendirinya tanpa usaha sebagai anugerah Allah. ${ }^{58}$ Ada tujuh maqam kenaikan rohani; tobat, wara', zuhud, faqr, sabar, tawakkal, redha. Hal/ abwal ada sepuluh; muraqabah, qurb, hub, khauf, raja', syauq, uns, tuma'ninah, mujahadah, yakin. ${ }^{59}$ Takwa, ikhlas dan syukur termasuk hal/ahwal ${ }^{60}$ jujur dan tauhid termasuk maqam. ${ }^{61}$ Maqam dan hal/ abwal dalam TSI tidak ada penjelasan.

a. Amaliah suluk.

1). Istigfar, permohonan ampun dengan membaca 'أستغراله, أستغر الله 'العظيم" mirip tobat meski ada perbedaan. Anggota TSI yang bersatus tertentu diharuskan membacanya sambil mengingat makna, 10.000 kali perhari, bisa menggunakan alat hitung. Bagi yang suluk dua hari membacanya $2 \times 10.000$ kali, hingga perkaliannya disesuaikan jumlah hari suluk. Yang suluk 40 hari membacanya $40 \times 10.000$ kali. Beristigfar sangat dianjurkan, bernilai mohon ampun kepada Allah (QS2:199), bertobat kepada-Nya (QS.11:60), (QS.2:54), bertobat dengan sebenarnya (QS.66:8). Rasul bersabda: aku istigfar/bertobat kepada Allah lebih 70 kali perhari (HR. Bukhari). ${ }^{62}$

2). Bershalawat atas Nabi 10.000 kali perhari, dengan lafal: " اللهم صل على سيدنا يُمَّ، 2 × 10.000 kali, yang suluk 40 hari x 10.000 kali. Bershalawat sangat dianjurkan

${ }^{57}$ Harun Nasution, Abuddin Nata, Akblak Tasawnf..., h. 62.

${ }^{58}$ Abuddin Nata, Abuddin Nata, Akblak Tasawuf..., h. 205.

${ }^{59}$ Simuh, Tasawnf dan Perkembangannya dalam Islam, (Jakarta: PT. Raja Grafindo Persada, 1977), cet. II, h. 49, 77, 99.

${ }^{60}$ Abuddin Nata, Abuddin Nata, Akblak Tasawnf..., h. 205

${ }^{61}$ Imam Abu al-Qasim al-Qusyairi, Risalat al-Qusyairiyah, diterjemahkan oleh Muhammad Lukman Hakim dengan judul Risalat al-Qusyairiyah, Risalah Gusti, (Surabaya, cet. X, t.th.) h. xxxvii-xxxviii.

${ }^{62}$ Imam Zakaria bin Yahya al-Syaraf, Riyadh al-Shalibin, diterjemahkan oleh Muchlih Shabir dengan judul Terjemah Riyadhal-Shalibin, Juz I, (Semarang: PT. Karya Thoha, 1981), h. 16. 
(QS.33:56) bermakna doa agar dirahmati. ${ }^{63}$ Banyak hadis yang menyuruh bershalawat disertai dengan keistemewaan-keistemewaannya.

3). Membaca Fatihah 1.000 kali perhari, yang suluk dua hari membacanya $2 \times 1.000$ kali dan yang suluk 40 hari x 1.000 kali. Allah mewahyukan tujuh ayat yang dibaca berulang yaitu surat Fatihah, ada yang mengatakan tujuh surat yang panjang ${ }^{64}$ Membaca Fatihah salah-satu rukun shalat (QS. 15: 87) dan menurut Nabi, tidak sah shalat tanpa membaca Fatihah" ${ }^{65}$

4). Membaca surat al-Ikhlas 1.000 kali perhari, yang suluk dua hari membacanya 2 x 1.000 kali, yang suluk 40 hari x 1.000 kali. Surat ini termasuk sangat penting karena berisi ajaran tauhid. Bicara tauhid bukti tekstualnya selalu merujuk surat ini. Keistemewaan membacanya sama membaca sepertiga alQur'an, tiga kali membacanya sama membaca sekali khatam al-Qur'an. ${ }^{66}$

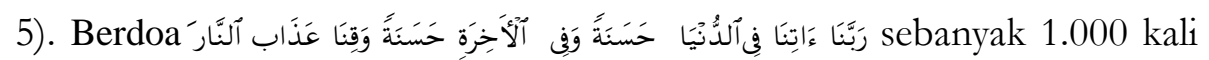
perhari, yang suluk dua hari membacanya $2 \times 1.000$ kali, yang suluk 40 hari x 1.000 kali. Doa ini penggalan ayat 201 al-Baqarah, permohonan keselamatan dunia-akhirat dan doa terbaik seorang muslim. ${ }^{67}$

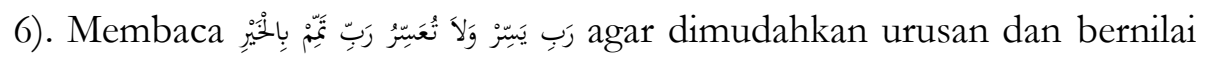
keberkahan. Dibaca 1.000 kali perhari, yang suluk dua hari membacanya $2 \mathrm{x}$ 1.000 kali, yang suluk 40 hari x 1.000 kali. Selain berusaha mengatasi problem diiringi doa mohon jalan ke luar terbaiknya.

7). Membaca doa tauhid, tidak ada Tuhan selain Allah dan Muhammad rasul Allah: 1.000 kali perhari, yang suluk dua hari membacanya 2 × 1.000 kali, yang suluk 40 hari x 1.000 kali. Doa ini cukup populer karena sering dibaca menjelang iqamat shalat fardhu.

8). Membaca لله سبحان 1.000 kali perhari, yang suluk dua hari membacanya $2 \times 1.000$ kali, yang suluk 40 hari x 1.000 kali. Membaca tasbih diperintahkan

${ }^{63}$ Departemen Agama RI, Al-Qur'an Dan Terjemahnya, (Bandung: Gema Risalah Press, 1989), h. 678.

${ }^{64}$ Departemen Agama RI, Al-Qur'an ..., h. 398.

${ }^{65}$ M. Arsyad al-Banjari, Sabilal Mubtadin, Juz I, (Indonesia: Dar al-Ihya al-Kutub al-Arabiyah, t.th), h. 136.

${ }^{66}$ Syekh Abd. al-Samad al-Falimbani, Siyar al-Salikin, Juz I, (Semarang: Maktabah wa Matbaah Toha Putera, t.th), h. 87.

${ }^{67}$ Departemen Agama RI, Al-Qur'an ..., h. 49. 
(QS.3:41), memuji Tuhan (QS.110;3). Setiap selesai shalat fardhu dianjurkan membaca سبحان الله kali, 33 kali. 33 kali, dan الله اكبر kali.

9). Setiap malam shalat tahajjud yang dianjurkan Islam (QS.17:79), dinilai ibadah yang membuat derajat diangkat Allah. Rasul melestarikan shalat tahajjud ini manifestasi kesyukuran dan pengabdian kepada Allah. ${ }^{68}$

10). Shalat Isyraq dan Dhuha. Shalat Isyraq adalah shalat sunat dua rakaat setelah matahari terbit, dilanjutkan shalat Dhuha, dua rakaat dan paling banyak delapan rakaat, waktunya hingga menjelang gelincir matahari. ${ }^{69}$

b. Amaliah pasca suluk

Setelah suluk selesai, pengikut dan pendukung berada pada pasca suluk dan menjadi anggota tetap TSI. Berkewajiban melaksanakan amaliah yang sama dengan amaliah suluk, ditambah membaca zikir dan asma al-husna. ${ }^{70}$ Hitungan membacanya 10\% dari jumlah yang dibaca masa suluk, kecuali tahajjud, Isyraq, Dhuha tetap dilakukan setiap hari/malam. Kemudian berzikir yang berarti menyebut nama Allah dan keagungan-Nya; bertasbih, tahlil, tahmid, takbir, berdoa, membaca asma al-busna, membaca al-Qur'an dan لااله الا الل

Dalam sufistik makna zikir diperdalam lagi bagi penghayatannya, hingga diartikan meninggalkan kealpaan memasuki musyahadah, mengalahkan rasa takut disertai kecintaan. ${ }^{71}$ TSI mewajibkan zikir dengan hati (bi al-qalb) dengan lafal Ł 山l sesekali menggerakkan bibir, kapan dan di mana pun asal jangan ditempat bernajis.

Niat dan hitungannya: Niat dan pahalanya untuk diri sendiri, 2.000 kali sehari selama 40 hari pertama. 5.000 kali perhari untuk 14 hari berikutnya, dan 10.000 kali perhari untuk 7 hari berikutnya. Untuk orang-tua, dibaca 7 hari berikutnya, 10.000 perhari. Untuk Nabi dibaca 7 hari berikutnya 10.000 perhari. Niat untuk para rasul, dibaca 7 hari berikutnya 10.000 perhari. Untuk para sahabat dibaca 7 hari berikutnya 10.000 perhari. Niat untuk wali, dibaca 7 hari berikutnya 10.000 perhari.Untuk muslimin, dibaca 7 hari berikutnya 10.000 perhari. Setelah putaran pertama selesai, kembali beramaliah putaran berikutnya dengan niat yang sama. Setiap putaran terhitung 104 hari dengan total zikir

\footnotetext{
${ }^{68}$ Syekh Abd al-Samad al-Falimbani, Siyar al-Salikin ..., h. 93.

${ }^{69}$ Syekh Abd al-Samad al-Falimbani, Siyar al-Salikin ..., h. 49.

${ }^{70}$ Wawancara dengan H.Abdullah al-Mahdi, ..., Banjarmasin, 24 Maret 2006.

${ }^{71}$ Imam Abu al-Qasim al-Qusyairi, Risalat al-Qusyairiyah ..., h. 262.
} 
640.000 kali. Setelah itu berkelanjutan mengamalkan zikir ini dengan niat/perhitungan seperti di atas. ${ }^{72}$

Zikir ada tiga; zikir lisan, zikir hati, zikir anggota. Tokoh sufi membaginya: zikir mata, zikir telinga, zikir lidah, zikir badan, zikir hati p, zikir roh. ${ }^{73}$ Zikir hati, tafakkur, merenungi kebesaran Allah didasari keyakinan yang tulus. ${ }^{74}$ Hal ini sama dengan zikir TSI yang menekankan zikir hati dan sama dengan zikir roh, nuansa halus dalam hati. ${ }^{75}$

Pengembangan zikir hati didukung tokoh-tokoh sufi, al-Qusyairi mengatakan, seseorang bisa mencapai zikir hati melalui zikir lisan, dan zikir hati membuahkan pengaruh sejati, bila mau meraih suluk sempurna gabunglah keduanya. Abu Usman ditanya orang yang berzikir lisan namun tidak merasakan kemanisan di hati. 'Pujilah Allah katanya, Dia menghiasi fisikmu dengan ketaatan ${ }^{76}$ mengisyaratkan zikir lisan dan zikir hati.

Al-Kurdi mengakui keduanya berdasar al-Qur'an dan hadis. Dikatakan, zikir lisan melafalkan huruf dan sulit dipraktikkan, zikir hati mengonsentrasikan pada makna. Karena itu Naqsyabandiyah memilih zikir hati, karena ia tempat pengawasan Allah, semayam iman, sumber rahasia dan cahaya $^{77}$. TSI membagi zikir hati kepada dua: dengan nama zat, dan dengan nafi

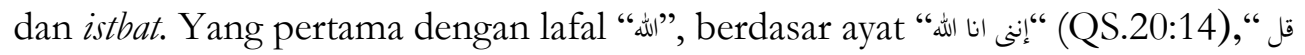

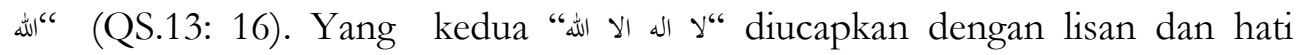
memaknai lafal "山ل “ل الأ hingga hati yang dalam. ${ }^{78}$ Jadi zikir hati TSI sama dengan yang berkembang di dunia sufi (al-Naqsyabandiyah.

Orang beriman diperintah berzikir (QS.33:41), Allah berzikir kepadanya (QS.2:152), berdiri duduk berbaring (QS.3:191), hati tenang karena rikrullah (QS,13:28). Tidak ada amal yang lebih menyelamatkan selain rikrullah. ${ }^{79} \mathrm{Al}-$ Qur'an/hadis ini tidak menjelaskan zikir lisan/hati, atau lisan dan hati

72Wawancara dengan H. Abdullah al-Mahdi, ..., Banjarmasin, 24 Maret 2006.

${ }^{73}$ Tim Penulis, Pengantar Imu Tasanuf, (Sumatera Utara: Proyek Pembinaan Perguruan Tinggi Agama IAIN Sumatera Utara, 1984), h. 1008-1009.

${ }^{74}$ Tim Penulis, Ibid, h. 109.

${ }^{75}$ Imam Abu al-Qasim al-Qusyairi, Risalat al-Qusyairiyah ..., h. 76.

${ }^{76} \mathrm{Imam}$ Abu al-Qasim al-Qusyairi, Risalat al-Qusyairiyah ..., h. 262-263.

77 Syekh Muhammad Amin al-Kurdi, Tanwir al-Qulub fi Mu'amalat 'Allam al-Guyub, (Singapura-Jeddah: al- Haramain, t.th), h. 508.

${ }^{78}$ Syekh Muhammad Amin al-Kurdi, Tanwir ..., h. 514.

${ }^{79}$ Al-Imam Muhammad bin Ismail al-Kahlani al-Shan'ani al-Makruf bi al-Amir, ..., h. 212. 
sekaligus. Berzikir hendaknya lisan dan hati sekaligus sebagaimana al-Qusyairi di atas, sebab zikir berarti mengingat dan mengucapkan. Penulis mengapresiasi amaliah zikir TSI dengan hati tanpa mengabaikan zikir lisan, terbukti adanya gerakan bibir. Zikir badan dengan pemanfaatan indera untuk hal terpuji secara otomatis teraplikasi dalam tarekat ini. Membaca asma al-husna yang sudah tersosialisasi di masyarakat bahwa mereka membaca dan menghayatinya sesuai anjuran Nabi. ${ }^{80}$ Menjadikannya sebagai amaliah adalah realisasi ajaran Islam. Allah memiliki asma al-husna berdoalah dengannya (QS.7:180), (QS.17:110). 'Allah mempunyai 99 nama yang agung, siapa yang menghafalnya masuk sorga'.

Amaliah jama'i yang berintikan kebersamaan adalah penunjang amaliah individual. Dimulai azan Magrib, shalat Magrib berjamaah, wirid Magrib, berzikir 100 kali dan doa, shalat sunat ba'diyah, shalat tobat dan istigfar, shalat hajat dan doa, membaca Yasin dan al-Mulk, shalawat dan doa. Menyusul azan Isya, shalat qabliyah Isya, shalat Isya, wirid Isya dan doa, shalat ba'diyah Isya, dan tausiah. $^{82}$

\section{Penutup}

Tasawuf Sufiyah Islam (TSI) dibangun oleh H. Abdul Muin Hidayatullah pada tahun 1955 setelah ia dibawa ke alam rohani. Menurut pengakuannya di alam rohani itu ia bertemu dengan Rasulullah, nabi Adam, nabi Musa dan 40 pimpinan negara Islam. Pertemuan demikian dalam kajian sufistik disebut liqa barzakhi. Saat itu ia dibai'at sebagai Mursyid Zahir, sementara Mursyid Batinnya adalah Rasulullah. Setelah dibai'at sebagai Mursyid Zahir, dengan segala kemampuan ia mulai mengembangkan tarekat ini. Setelah ia meninggal dunia (1995), kepemimpinan tarekatnya dilanjutkan oleh mursyid penggantinya yaitu anaknya sendiri yang bernama K.H. Abdullah al-Mahdi dan mengembangkannya hingga sekarang.

TSI dalam pemikiran tasawuf $\mathrm{H}$. Abdul Muin ini merupakan tarekat baru, karena hingga sekarang tidak tercantum dalam deretan tarekat yang berkembang di dunia Islam, meski pun unsur ketarekatannya terpenuhi.

\footnotetext{
${ }^{80} \mathrm{Al}-\mathrm{Imam}$ Muhammad bin Ismail al-Kahlani al-Shan'ani al-Makruf bi al-Amir, Ibid, h. 109.

${ }^{81}$ Abi Abdillah Muhammad bin Ismail bin Ibrahim ibn al-Mughirah bin Bardizbah alBukhari, Shabih al-Bukhari, Jilid III Juz IX, (Mesir: Dar al-Fikr, t.th), h. 145. Lihat juga al-Imam Muhammad bin Ismail al-Kahlani al-Shan'ani al-Ma'ruf bi al-Amir, ..., h. 108.

${ }^{82}$ Wawancara dengan H.Abdullah al-Mahdi, ..., Banjarmasin, 30 Maret 2006.
} 
Kecuali itu diketahui bahwa silsilah mursyidnya tidak bersambung (muttasi), karena menurut mursyidnya, ia langsung menerimanya dari Rasulullah (liqa barzakbi).. Secara teori, silsilah musyid harus bersambung hingga memenuhi kriteria sebagai tarekat muktabarah, meski ada sebagian tokoh sufi mengatakan bahwa liqa barzakbi bisa saja terjadi hingga tarekat ini tidak berbeda dengan tarekat lainnya. Namun sebagiannya menolak karena hal itu sulit dibuktikan secara imperis.

Pengikut tarekat ini berjumlah 7.000 orang yang tersebar di Kalimantan Selatan terutama di Banjarmasin, Tabunganen dan di Kabupaten Tabalong (Tanjung). Mereka terbagi dalam empat klasifikasi: pendengar, pelajar, pengikut dan pendukung. Yang berstatus 'pendengar' merupakan tingkat pemula yang hanya menyerap informasi. Bagi yang berstatus 'pelajar' mulai diadministrasikan, dan yang berstatus 'pengikut' dan 'pendukung' dianggap sebagai anggota yang sebenarnya, membantu kelangsungan TSI dan ikut menyebarkan ajarannya. Untuk sampai kepada dua 'status' terakhir ini, para anggota diwajibkan mengikuti suluk dan pasca suluk, dengan mempraktikkan amaliah/ajaran (wirid) tertentu berupa istigfar, shalawat dan lain-lain. Selain itu bagi yang berada pada 'pasca suluk' diwajibkan qikrullah puluhan-ribu perhari dengan menekankan pada aspek zikir hati (qalb).

\section{Daftar Pustaka}

Abdullah, Hawas, Perkembangan Ilmu Tasawnf dan Tokob-Tokobnya di Nusantara, al-Ikhlas, Surabaya, t.th.

Anshary AZ, HA Hafiz, Islam di Kalimantan Selatan (Peranan Syekh Muhammad Arsyad al-Banjari di Dalam Pengembangan Islam di Kalimantan Selatan),dalam Khazanah Vol. 1 No. 1. 1 Januari-Februari 2002, Banjarmasin, IAIN Antasari, 2002.

Atjeh, Abubakar, Pengantar Ilmu Tarikat, Kajian Historis tentang Mistik, Ramadhani, Solo, 1994.

Al-Aziz, Muhammad Saifullah, Risalah Memahami Ilmu Tasawnf, PT. Terbit Terang, Surabaya, 1998.

-------, Tasawuf dan Jalan Hidup Para Wali, Putera Pelajar, Surabaya, 2000.

Bahreisy, Salim, Irsyad al-Tbad Ila Sabil al-Rasyad, (Petunjuk ke Jalan Lurus) Dar alSegaff. PP. Alawy, Surabaya., t.th. 
Al-Banjari, M. Arsyad, Sabilal Mubtadin, Dar al-Ihya al-Kutub al-Arabiyah, Indonesia, t.th.

Al-Barsany, Noor Iskandar, Tasawuf Tarikat dan Para Sufi, PT. Raja Grafindo Persada, Jakarta, 2000.

Bruniessen, Martin Van, Tarikat Naqsyabandiyah di Indonesia, Mizan, Jakarta, 1999. cet. IV.

Al-Bukhari, Abi Abdillah Muhammad bin Ismail, Shahih Bukhari, Dar al-Ihya Maktabat al-Arabiyah, Indonesia, t.th.

Al-Dimasyiqi, Sykeh Jamaluddin al-Qasimi, Mauizat al-Mukminin min Ibya Ulum al-Din, diterjemahkan oleh M. Abdai Ratomi dengan judul Bimbingan Untuk Mencapai Hidup Mukmin, CV. Diponegoro, Bandung, 1973.

Djaelani, Abdul Qadir, Koreksi Terhadap Ajaran Tasawuf, Gema Insani Press, Jakarta, 1996. cet. I.

Al-Falimbani, Syekh Abd al-Shamad, Hidayat al-Salikin, Syirkah al-Ma'arif alThaba' wa al-Nasyr, Bandung, t.th.

-------, Siyar al-Salikin, Maktabah wa Mathba'ah, Toha Putra, Semarang, t.th.

Al-Ghazali, Imam, Ihya Ulum al-Din, Dar al-Fikr, Beirut, Jilid III, t.th.

Hamdi, Ilham Masykuri, Ajaran Tasawuf Syekh Mubamad Nafis al-Banjari, IAIN Syarif Hidayatullah, Jakarta, 1989.

Hamka, Tasawuf Perkembangan dan Pemurniannya, Pustaka Panjimas, Jakarta, cet. XI, 1984.

Al-Husaini, Muhammad bin Abdullah bin, al-Fath al-Rabbani fi Man Yabtaj Ilaibi al-Murad al-Tijani, t.p, t.tp, t.th.

Isa, Abdul Qadir, Haqaiq al-Tasawnf, diterjemahkan oleh Khairul Amru Harahap dan Afrizal Lubis dengan judul Hakikat Tasawuf, Qisthi Press, .t.tp, cet. I, 2005.

Isa, Ahmadi, Ilmu Tarikat, Pascasarjana IAIN Antasari, Banjarmasin, 2005.

-------, Ajaran Tasawuf Sykeh Mubammad Nafis al-Banjari, (Disertasi), IAIN Syarif Hidayatullah, Jakarta, 1989.

Ismail, H. Usep Usman, Apakah Wali itu Ada, PT. RajaGrafindo Persada, t.tp, 2005. 
Al-Kahlani, al-Imam Muhammad bin Ismail, Subul al-Salam bi Syarh Bulugh alMaram min Adillat al-Abkam, Dar al-Fikr, Beirut, Juz II, t.th.

Al-Kalabazi, at-Ta'aruf ila al-Mazhab Abl al-Tashawnuf, Dar al-Qahirah, Mesir, t.th.

Al-Kurdi, Muhammad Amin, Tanwir al-Qulub fi Mu'amalat 'Allam al-Guyub, alHaramain, Jedddah, Singapura, t.th.

Mahdi, K.H, Abdullah dan Noor, H. Busera, Kumpulan Beberapa Naskah Hasil Perjalanan Tarikat Sufiyah Islam, Yayasan Hidayatullah, Banjarmasin, 1416 $\mathrm{H} / 1996 \mathrm{M}$.

Mahmud, Abd. al-Halim, Qadliyat al-Tashawnuf al-Munqiz. min al-Dhalal, diterjemahkan oleh Abu Bakar Basymeleh dengan judul Hal Ihwal Tasawnf, Dar al-Ihya, Indonesia, t.th.

Mansur, M. Laily, Ajaran dan Teladan Para Sufi, Bulan Bintang, Jakarta, 1990.

Mathar, al-Syekh Husin, et.al, al-Targbib wa al-Tarbib,Madrasah al-Falah, Mekkah al-Mukarramah, Juz II, t.th.

Mulyati, Sri, at.al, Mengenal dan Memahami Tarekat-Tarekat Muktabarah di Indonesia, PT. Pranada Media, Jakarta, 2004.

Muslim, Imam, Shabih Muslim, PT. Ma'arif, Bandung, Jilid. I, t.th.

Mustofa, HA, Akblak Tasawnf, CV. Pustaka Setia, Bandung, Edisi Revisi, cet. II, 1999.

Nasution, Harun, Filsafat dan Misticisme dalam Islam, Bulan Bintang, Jakarta, cet. VII, 1990.

Nata, Abuddin, Akblak Tasawnf, PT. Raja Grafindo Persada, Jakarta, cet. IV, 2002.

Al-Qusyairi, Abu al-Qasim, Risalat al-Qusyairiyah, diterjemahkan oleh Muhammad Lukman Hakim dengan judul Risalat al-Qusyairiyah, Risalah Gusti, Surabaya, cet. X, t.th.

Simuh, Tasawnf dan Perkembangnya dalam Islam, PT. RajaGrafindo Persada, 1977. cet. II.

Solihin, M. Melacak Pemikiran Tasawuf di Nusantara, PT. RajaGrafindo Persada, 2005. 
Spencer, J. Trimingham, The Sufi Orders in Islam, Oxford University, London, 1971.

Syafruddin, Tarikat al-Tijaniyah di Kalimantan Selatan (Studi Sejarah dan Motivasi Masyarakat Masuk Tarikat (Tesis), Pascasarjana IAIN Antasari, Banjarmasin, 2003.

Syamsuri, Tarikat al-Tijaniyah Tarikat Eksklusif dan Kontroversial, dalam Mengenal dan Memahami Tarikat-Tarikat Muktabarah di Indonesia, Pranada Media, Jakarta, Edisi I, 2004.

Al-Syaraf, Imam Zakaria bin Yahya, Riyadl al-Shalibin, diterjemahkan oleh Muchlin Shabir dengan judul Riyadl al-Shalibin, PT. Karya Thaha, Semarang, Juz I, 1981.

Syukur, M. Amin, Menggugat Tasawnf, Pustaka Pelajar, Yogyakarta, cet. I, 2002.

Syukur, M. Asywadie, Ilmu Tasawnf, PT. Bina Ilmu, Surabaya, Jilid I, 1978.

-------, Perkembangan Ilmu Keislaman di Kalimantan, makalah Seminar on Islamic Reference in The Malay Word, Brunei Darussalam, 2002.

-------, Pemikiran-Pemikiran Syekh Muhammad Arsyad al-Banjari dalam Bidang Taubid dan Tasawuf, t.p. Banjarmasin, 2004.

Tim Penyusun, Pengantar Ilmu Tasawnf, Proyek Pembinaan Perguruan Tinggi Agama IAIN Sumatera Utara, Sumatera Utara, 1984.

Al-Tirmizi, al-Hakim, Kitab Khatam al-Auliya, al-Maktabah al-Katolikiyah, Beirut, 1965.

Al-Tijani, Muhammad Said bin Abdullah al-Rabat bin, al-Karar al-Saniyah fi alSyuruth al-Aurad al-Tariqat al-Tijaniyah, diterjemahkan oleh KH. Maftuh Said dengan judul Mutiara Penjelasan Syarat dan Wirid-Wirid Tarikat al-Tijaniyah, Pondok Pesantren Munawwariyah, 1950.

Zahri, Mustafa, Kunci Memahami Ilmu Tasawnf, PT. Bulan Bintang, Surabaya, 1979. 
